Maurice A. Deane School of Law at Hofstra University Scholarly Commons at Hofstra Law

Hofstra Law Faculty Scholarship

1999

\title{
Reclaiming Social Rights: International and Comparative Perspectives
}

Barbara Stark

Maurice A. Deane School of Law at Hofstra University

Follow this and additional works at: https://scholarlycommons.law.hofstra.edu/faculty_scholarship

\section{Recommended Citation}

Barbara Stark, Reclaiming Social Rights: International and Comparative Perspectives, 21 Hum. Rts. Q. 547 (1999)

Available at: https://scholarlycommons.law.hofstra.edu/faculty_scholarship/179

This Article is brought to you for free and open access by Scholarly Commons at Hofstra Law. It has been accepted for inclusion in Hofstra Law Faculty Scholarship by an authorized administrator of Scholarly Commons at Hofstra Law. For more information, please contact lawcls@hofstra.edu. 
King Leopold's Ghost: A Story of Greed, Terror, and Heroism in Colonial Africa by Adam Hochschild (Boston: Houghton Mifflin Company, 1998).

All the great advances in human rights have been-and will continue to bemade at that critical moment of moral judgment when men and women confronted with abuse react with outrage and make a decision. They decide that despite all of the tradition, prevailing assumptions, pressures from vested interests, and resistance aligned against them, they will no longer be willing to simply accept things as they are, no longer be passive, and no longer be silent. They become willing to risk their families, their friendships, their jobs, their reputations, their security, and sometimes even their lives on behalf of those who suffer.

Once they became aware of the unspeakable suffering of the Middle Passage across the Atlantic, for example, Thomas Clarkson and William Wilberforce determined to commit their lives toward ending the slave trade. The personal experience of holding wounded soldiers writhing in agonizing pain without medical attention led Henry Dunant to create the International Red Cross. Witnessing the terrible plight of thousands of helpless people fleeing their homelands in the wake of war and revolution in order to save their lives convinced Fridtjof Nansen to devote himself to protecting the rights of refugees. The realization of the unimaginable genocide of the Holocaust convinced many in the world, like Eleanor Roosevelt, of the need to work tirelessly on behalf of establishing international standards of human rights. The arbitrary arrest of students for toasting "to freedom" moved Peter Beneson to launch a letter writing campaign that eventually became Amnesty International. All of these actions, and countless others by those known and unknown from the globe to the grassroots, flow from decisions made at moments of moral choice.

This essential element in understanding and appreciating the historical evolution of human rights is captured in all of its drama, pain, and courage by Adam Hochschild in his blistering book, King Leopold's Ghost, and appropriately subtitled A Story of Greed, Terror, and Heroism in Colonial Africa. At the end of the nineteenth century, King Leopold of Belgium became obsessed with seizing control of territory in Africa. Like many other Europeans and Americans of his day, he viewed the continent as if it were without Africans: a vast expanse of uninhabited space, just waiting with unlimited possibilities for prestige and profit. The Congo appeared ripe for the taking. With charm, seductive rhetoric, political guile and deviousness, propaganda and sham organizations, bribes, hidden accounting, manipulation, the ruthless use of the military power of the state, and boundless greed, Leopold set out to make the Congo his personal fiefdom. Brutal exploitation and the forcible extraction of tons of ivory, and then shiploads of rubber, soon brought him staggering wealth.

Like all oppressive regimes, of course, the success of Leopold's operation 
required those willing to follow orders. He needed explorers, military officers and men, steamboat captains, state functionaries, concession company officials, foremen, and soldiers of fortune, among others, willing to accept the prevailing attitudes of racial superiority over indigenous peoples, to do exactly what the system told them to do without asking troublesome questions, to inflict pain or kill, and to keep quiet. He had no difficulty finding such people. Indeed, an important measure of his success in this regard can be seen in the fact that he was able to hide the brutality of his operation and actually portray himself as a philanthropic monarch and the Congo as a veritable model of progress and civilization for years without challenge.

But not everyone can be bought or persuaded. Through Hochschild's impassioned and riveting account, we find visitors with different eyes and different values traveling by foot around the lower rapids and by steamer up the river into Leopold's hidden and lucrative Congo. One of these is a black American named George Washington Williams, a Baptist minister and writer. To his shock, he discovers not the paradise of a benignly ruled colony and well-treated people as described by all of Leopold's propaganda, but instead a horrifying regime of brutality characterized by kidnaping, chain gangs, theft, repression, and torture. At that moment, he decides to no longer be silent in the face of such barbarity and speak out in defiance of a king, his officials, and the racial order of the day. He begins by writing powerful and angry letters and then reports to Leopold, to the president of the United States, and finally to the world, systematically and comprehensively documenting the violations of human rights and explicitly charging Leopold (decades before the Nuremberg trials) of committing "crimes against humanity."

Other unsuspecting visitors follow. William Sheppard, a black Presbyterian missionary sent from America to minister to the needs of indigenous peoples in the Congo, suddenly finds himself in the midst of a cataclysm. Refugees flood into his mission station with reports of terror and genocide. As he goes into the bush to investigate, he discovers bloodstained ground, destroyed villages, bodies, the stench of rotting flesh, and hands-piles of right hands cut off by Belgians as punishment or as evidence of the numbers of Africans killed. The experience compels Sheppard, at great risk to himself, to speak out on behalf of the victims who could not speak for themselves. Very slowly, other voices are added, such as that of Roger Casement, the Irishman sent as a member of the British consular service into the region, and Joseph Conrad who, after brooding over his own Congo experiences for eight years, decides to publish Heart of Darkness. This book, as Hochschild explains with considerable literary and historical sophistication, revealed to the world the horrors that Leopold wanted to remain hidden: the lash of the chicotte or whip of hippopotamus hide, the severed hands, the heads mounted on the fenceposts of white officials for ornamentation, and the hearts of those who would brutalize so many innocent men, women, and children. Not surprisingly, Leopold did whatever he could to discredit and silence these accusers among missionaries or travelers sympathetic to natives with first-hand experience in the Congo who threatened to expose his apparatus of exploitation.

But sometimes in the historical struggle for human rights voices come in unexpected ways from unanticipated 
sources. One of these is that of Edmund D. Morel, a sober, respectable, thoroughly conventional businessman-an insider who had everything to gain by simply doing what he was told to do. As a trusted employee of a Liverpool shipping company, he was sent to Belgium to supervise the loading and unloading of ships on the Congo run. Although his fellow company officials had been handling this shipping traffic for years without so much as a second thought, Morel began upon inspection to notice things that unsettled him. The accounting figures in the books do not match the reports issued by the Belgian government. When ships arrive at the Antwerp docks from the Congo, they are filled to the hatch covers with valuable cargoes of ivory and rubber. Yet, when they leave to go back to the Congo, while military bands play on the pier and eager young men in uniform line the ship's rails, what they carry back is mostly more army officers, firearms, and ammunition for modern rifles. In other words, it begins to dawn on Morel that there is no trade going on here at all. As Morel watches these riches streaming to Europe with almost no goods being sent back to Africa to pay for them, it gradually begins to dawn on him that he is staring into the face of evil, for there can be only one explanation: slavery.

When faced with this fateful moment of decision, and in smoldering outrage compounded by company efforts to coerce and then bribe him, Morel refuses to be quiet. At great personal risk, with a sick mother and family to support, and as seemingly an unlikely person to become the leader of one of the great crusades for human rights, he quits his job and sets about to expose what he calls Leopold's "legalized infamy." "I had launched the boat," he later wrote, "and there could be no turning back."
Morel went on to become one of the most influential activists of his time, writing books, dozens of pamphlets, and hundreds of articles and letters to the editor all designed to expose atrocities in the Congo. He developed techniques that later would be used by Amnesty International and other human rights campaigners: give as wide a publicity as possible to abuses, but report with meticulous accuracy and verifiable facts. In this regard, he discovered the powerful impact of photographs-visual images of devastated villages, of piles of bodies, of children sitting next to severed feet and hands-that no amount of official propaganda could possibly refute and capable of producing that moment of moral decision in others.

Indeed, the response to Morel's photographs and facts, as well as his own personal courage, integrity, and passion, was a widespread international movement on behalf of human rights. Only a few years after standing on the docks at Antwerp, Morel would found the NGO of the Congo Reform Association and be the inspiration behind nearly three hundred gatherings a year in Britain, some of which would attract nearly five thousand people at a time, and more than two hundred meetings across the United States. He would mobilize Mark Twain, the Archbishop of Canterbury, Booker T. Washington, Anatole France, members of Parliament, peers, clergy, editors of major newspapers, millionaires and factory workers alike, and thousands of others to sign petitions designed to mount a campaign against injustice by exerting relentless, growing pressure upon the governments of Belgium and several other major countries to change course in Africa. In the process, they contributed tremendously to the evolution of international human rights by building a vision of duties beyond borders-a sense 
of responsibility and a capacity for outrage at pain inflicted upon another human being, regardless of whether that human being was of another color or another country at another end of the earth.

For those readers interested in the broad subject of human rights, one of Hochschild's most important contributions is his ability to go beyond his immediate historical case study and see the larger issues that it raises. His last chapter entitled "The Great Forgetting," for example, views Leopold's extraordinary efforts to hide the truth of his brutality in the Congo as very much in keeping with other and more recent regimes that systematically attempt to erase potentially incriminating evidence of human rights violations from the historical record. Press censorship, book banning, destruction of files, suppression of witnesses, and the silencing of victims have been, and remain, the essential tools of those who want people to forget and of those for whom history is threatening. As Hochschild points out, at the time of the Congo controversy a hundred years ago, the idea of human rights was a profound threat to oppressive regimes. It still is.

Paul Gordon Lauren Regents Professor The University of Monitana and author of the recent Evolution of International Human Rights: Visions Seen

\section{The Graves, Srebrenica and Vukovar, by Eric Stover and Gilles Peress (Zurich: Scalo, 1998), 329 pp.}

In this book, science writer Eric Stover and photojournalist Gilles Peress confront the reader with evidence of recent atrocious carnage carried out in the former Yugoslavia in the name of "ethnic cleansing." Complimenting Eric Stover's narrative of the exhumation process of mass graves, are Gilles Peress' accompanying photos, which are gutwrenching and startling in the realism with which they present the faces of survivors and intertwined cadavers dumped in and near the star-crossed villages of Srebrenica (Bosnia) and Vukovar (Croatia).

In bringing the reader photographically face-to-face with victims and survivors of monstrous crimes, the authors make a very unusual addition to the human rights literature. The volume effectively succeeds, on many levels, in combining historical elements graced with full character development of the principals in a presentation that reads like a novel. Moreover, this piece of riveting photojournalism and very readable text is enhanced with accessible explanations of the science employed in the exhumation process.

As a science thriller, The Graves places the reader side-by-side with forensic anthropologists, Bill Hagland, Clyde Snow, and their associates, and their hunt for evidence of culpability that is revealed gradually by the harrowing routine of daily exhumations and painstaking examinations that is conducted near a Bosnian and a Croatian village, where civilians were wantonly murdered and their bodies deposited in mass graves. Stover's account, reflecting site visits and many interviews, makes the reader feel like a silent, but haunted, 
witness, of such carnage. For example, Stover recounts listening to Marko, an informant, describe the slaughter by Serb soldiers of Croatian patients driven out of the Vukovar hospital and onto the killing fields of the Ovcara farm. At the same time, the author's literary zoom lens gives the vicarious witness a distressing closeup:

As the archeologists dug deeper, they discovered bodies wearing smocks and white clogs, garb common to hospital employees in Europe. Some of the bodies bore signs of previous injuries: a thigh bandaged in gauze or a broken arm set in a plaster cast and sling. A pair of broken crutches lay on top of one body. Another had a catheter dangling from its pelvis.'

The only crime the victims committed was that they were not Serbs. In other cases, usually on the basis of the words of survivors, the author acquaints the reader with other criminal actions by Croats and Bosnian Muslims.

The scores of high resolution photos in this book are terribly sad; they are pictures from hell bringing to mind Secretary of State Warren Christopher's description of the Balkan conflict in the early 1990s as a "problem from hell." Among the reasons for his judgment is the frightful scope and hateful manner of human slaughter involved. Of course, wasting human beings is what war is all about, and such depravity is nothing new. For example, to note a historical counterpart, large-scale carnage was also the distinctive marker of the Crimean War of 1854 to 1856 , sometimes called the first modern war because of the fire power used. The scope of senseless and inhumane cruelty, personally viewed on the battlefield in 1859 by Henri Dunant inspired him to propose the establishment of an international body for the aid of the wounded-an idea that was finally realized in the Geneva Convention of 1864 and the founding of the International Committee of the Red Cross. While witnessing mass atrocities can indeed be a crushing human experience, Durant's case suggests that it can also stir the conscience and energize the will to creative action.

Visions of human slaughter from the same nineteenth-century battlefield also brought the Strasbourgeois artist, Paul Gustave Doré, to use his meticulous and photography-like sketches to dispatch pictures from the war zone, prompted by a "people must see this" kind of moral imperative. In turning from life to art, from The Crimea to Dante's Inferno, Doré's skills of artistic steel-plate engraving are remembered today for unrolling an aesthetic panorama of misery and cruelty. ${ }^{2}$ Among the most famous is a fearful etching of the Florentine poet being lowered into the Inferno, sighing, "Yet in the abyss . ..., Lightly he placed us." ${ }^{3}$ Dante's Canto $X X X 1^{4}$ from the $I n$ ferno could as well have dedicated and inscribed the amazing photographic studies by Gilles Peress, a prize-winning French photojournalist internationally famous for dramatic pictures transmitted from dangerous places. Like Doré's presentation of the poet's netherworld, Peress places us in the abyss and confronts us with varied localities full of

1. Eric Stover \& Gilles Peress, The Graves: Srebrenica and Vukovar 232-33 (1998).

2. Alichuieri Dante, Inferno (Henty Francis Cary trans., Thompson \& Thomas) (1908) (illustrated with designs of Gustave Doré).

3. Id. at 147.

4. Id. at 144 . 
dolorous light searing the memory by their alarming and sublime realism. Peress' photos give the book an extraordinary dimension, turning it into a source for meditation.

In ways impossible to forget, Peress' photos in The Graves bring our eyes in contact with the ghastly night shades of hell. They challenge us, as Henri Dunant was once challenged, to transcend the need to weep and to seek an equally human response in search of remedies. An effective and permanent international court of criminal justice comes to mind.

On a different level, the text is a useful contribution to the new literature on science in the service of human rights-an important emerging field of human rights activism. While The Graves does not say so, the reader may know that Eric Stover played a major role in these developments as the Director of the Science and Human Rights Program of the American Association for the Advancement of Science ("AAAS"), and later as the Director of Physicians for Human Rights. Under his leadership in 1983, the AAAS responded to Argentine requests for technical investigative assistance when a new civilian government displaced the military government, and appointed a national commission to delve into human rights abuses under previous regimes. Stover's precedent-setting task was to mobilize the expertise of various scientific disciplines in support of the Argentine investigations. In work that laid the technical basis for later efforts to combat impunity elsewhere, graves were opened, and skeletons were exhumed and analyzed by the methods of forensic anthropology to confirm execution-style killings and, in many instances, the signs of partially healed injuries from torture.
In addition, dental and medical records were used to establish identity. In a number of cases, forensic examination of skeletons and autopsies on prisoners, who died in custody, refuted the claims of captors that the deaths were due to natural causes. Molecular biologists brought the power of blood-typing and later mitochondrial DNA sequencing to bear on issues of kidnaped children and separated families. These techniques, in a constructive process of human rights technology transfer, were later used. in Brazil, Guatemala, and Kurdistan, and, as documented in The Graves, most recently in the former Yugoslavia. Indeed, reflecting this history, the recent forensic teams at the Srebrenica and Vukovar grave sites included technicians from Argentina, Chile, and Guatemala, all former protégés of Clyde Snow, who ten years before set the standards for such work sponsored by the AAAS.

College teachers may wish to assign the book to supply students with as near a first hand experience of gross human rights violations as they might encounter outside of the bubble of first world comfort. Law students may wish to read the book in combination with Mark Osiel's Mass Atrocity, Collective Memory and the Law. ${ }^{5}$ Osiel argues that the trials of those responsible for large-scale politically motivated brutality often capture public imagination, helping to engage large questions of historical interpretation of fratricidal events.

Richard Pierre Claude
Founding Editor
Human Rights Quarterly
Professor Emeritus of Government and
Politics, University of Maryland

Richard Pierre Claude Founding Editor 
Masses in Flight: The Global Crisis of Internal Displacement, Roberta Cohen \& Francis M. Deng (Washington, D.C.: The Brookings Institution, 1998), 436 pp.; The Forsaken People: Case Studies of the Internally Displaced (Roberta Cohen \& Francis M. Deng eds., Washington, D.C.: The Brookings Institution, 1998), $512 \mathrm{pp}$.

More than any other person, Francis Deng, the former Sudanese diplomat, has put the issue of "internally displaced persons" on the international human rights agenda, adding it to the growing weave of rights-based, institutionalized concern for vulnerable people that is one of the hallmarks of the second half of the twentieth century.

Deng was appointed Representative of the UN Secretary-General on Internally Displaced Persons (IDPs) in 1992. The mandate-issued by the UN Commission on Human Rights, reaffirmed by UN resolutions, and subsequently renewedwas to study the causes and consequences of internal displacement, the status of the internally displaced in international law, the extent to which these needs were addressed by current institutional arrangements, and ways to improve protection and assistance. Empowered with this mandate, Deng has been a tireless advocate of the internally displaced, arguing that the international community has both a right and an obligation to aid them. His numerous reports to the United Nations (UN) have documented the plight of IDPs throughout the world. Working with a team of legal experts, he has compiled an analysis of existing legal norms that support the provision of international protection and assistance. At the request of the UN, these norms were formalized into a set of principles designed to induce states and rebels to treat the victims of conflict according to standards consistent with human rights and international humanitarian law, and to encourage aid organizations to assist them accordingly. Adopted by the Commission on Human Rights in 1998, the Guiding Principles on Internal Displacement were also to be a principal instrument for Deng to look after the needs of the IDPs in his continued capacity as the Representative of the Secretary-General.

This work has contributed to the wide recognition of IDPs as a particular group of vulnerable persons. Their status recognition is indicated by the fact that several UN resolutions specifically identify them as a category of beneficiaries, even in cases where they would seem to be covered by the more general wording. For instance, Security Council Resolution 929, which authorized the French intervention in Rwanda toward the end of the 1994 genocide, empowered Operation Turquoise to contribute to "the security and protection of displaced persons, refugees, and civilians at risk." While not all civilians at risk might be displaced, presumably all displaced persons entitled to protection would be covered under the category "civilians at risk." Yet, their identification as a distinct group of beneficiaries speaks to the success of the efforts in the 1990s to aid the IDPs.'

Another reason for the greater recognition of IDPs originates in the selfish

1. Another explanation would be that the resolution was deliberately drafted to permit the French forces to protect and assist displaced persons who were not civilians, i.e. the Hutu militia and government soldiers who were fleeing the advancing RPF forces. This would be contrary to the main principles of international humanitarian law, and seems unlikely. 
interests of states. Protecting persons within their own state can of course be a substitute for conventional asylum in other countries. As many governments in the 1990s judged the actual or potential burden of conventional asylum to be excessive, the interest in developing a regime for IDPs increased.

The claims of IDPs to international protection and assistance are grounded in human rights, international humanitarian law, and the principles on which international refugee law is founded. As a matter of strategy, advocates for IDPs commonly take the similarities between the internally displaced and international refugees as their starting point. Besides the fact that refugees have crossed an international border and IDPs have not, their deprivations and need for assistance are basically similar. Hence, the discrepancy in treatment whereby (international) refugees are receiving international aid, but (internally) displaced persons are not, violates a sense of basic fairness as well as humanitarian principles.

The critical difference, of course, is that the IDPs are still located within the bounds of the state that often caused their misfortune. Unless the state concerned readily agrees, aiding IDPs is an enormously more complex task politically and legally speaking. The reasons for aiding IDPs therefore must be elaborated, and this is the principal objective of the present two-volume publication by Francis Deng and Roberta Cohen.

The publication draws on the work done by Deng and his associates for the United Nations. Published by the Brookings Institution, where Deng is a senior fellow in the Africa program, the work follows a briefer analysis of the IDP problem that Deng wrote for Brookings in 1993 (Protecting the Dispossessed). With 900-plus pages, this is a massive elaboration of the earlier, slim version. The two volumes are edited and partly written by Deng and Roberta Cohen, a noted US human rights expert and colleague of Deng at Brookings. The first volume (Masses in Flight) provides an overview of the problem: it describes the causes and conditions of IDPs in the contemporary world, analyzes the legal and institutional framework for assisting them, and identifies the principal policy strategies. The second volume (Forsaken People) is a compilation of case studies on the conditions of IDPs written by different authors.

Deng and Cohen do not systematically examine what determines success or failure of attempts to aid IDPs, nor, for that matter, why more efforts are made in some cases than in others. There is no comparative analysis of the rich empirical material presented in the case studies. Rather, the authors have set themselves a different task, closer to what Richard Rorty approvingly calls to advance our "sentimental education": to understand emphatically what it means to be internally displaced and why this concerns us; to discern where in the maze of international soft and hard law are the principles located that can pressure, $\mathrm{ca}$ jole, threaten, or circumvent those who oppose the provision of aid to IDPs; and finally, how we can identify institutions for legitimate action.

The publication has an encyclopedic quality to it, and as such is uniquely valuable. In addition to drawing on the material produced for the Commission of Human Rights, it has several original chapters. There is a fresh analysis of the institutional framework in the UN system for aiding IDPs and of responses by regional organizations. The chapter on legal principles is based on the Compilation and Analysis of Legal Norms that a group of experts did for the Commission 
on Human Rights and which was eventually articulated in The Guiding Principles on Internal Displacement. The ten case studies are written by close observers, some of whom have practical experience from humanitarian emergency responses. Together, they form a thick narrative of misery, interspersed with hope, from Africa (Burundi, Rwanda, Liberia, the Sudan), the former Yugoslavia, the Caucasus, Central Asia (Tajikistan), South Asia (Sri Lanka), and Latin America (Colombia and Peru).

Cohen and Deng conclude that present legal norms for providing protection and assistance, while adequate in some respects, contain significant lacuna. The institutional framework is weak. There is no single agency in the UN system specifically mandated to look after the IDPs—mainly because the UN is an organization of states and the IDPs are often a contested population within the internal jurisdiction of a state. Partly for that reason Deng and Cohen do not recommend establishing a new agency with responsibility for aiding IDPs in an emergency. Strengthening the existing system of lead agency is seen as a more workable solution. On the policy side, the recommendations are generally noncontroversial as well: more efforts must be made to prevent and manage conflicts so as to avoid the disruption of populations in the first place.

More controversial is the central premise of the book, that is, that the international community has a right, indeed an obligation, to assist internally displaced persons who are in life-threatening circumstances with or without the consent of the state concerned. Arguing that sovereignty carries the responsibility to protect and give life-supporting assistance to the subject population, Deng and Cohen conclude that a state that forfeits that responsibility "would be ex- pressly required to accept offers of humanitarian assistance." States that refuse aid "should expect calibrated actions that range from diplomatic demarches to political pressures, sanction, or, as a last resort, military intervention." The right and duty to provide aid stems from the principle of subsidiary sovereignty: if a state in question fails to provide the most basic protection and assistance to its subjects, then the responsibility falls to the international community.

This, of course, is a highly controversial position in both a legal and political context, and has been widely debated in recent literature. Deng and Cohen do not enter into this discussion. There is no articulation of how to reconcile contradictory norms and policy imperativesnotably between that of intervening to assist a needy population, and of respecting the principle of non-intervention that gives some stability and order to the present international system. There is no assessment of how to handle unintended consequences of moral actions, for instance, when humanitarian aid for IDPs tends to prolong or exacerbate war.

Deng and Cohen make the kinds of simplifying assumptions that perhaps are necessary to take a bold moral stance. They assume that the overriding and primary responsibility of sovereignty is to protect and assist the subject population. They do not recognize other responsibilities of sovereignty that may be conflicting and give rise to difficult dilemmas of action, e.g. the responsibility to maintain order internally and contribute to stability and security internationally. Like Grotius, Deng and Cohen further assume the innocence of civilians in situations of armed conflict. In its Grotian form, the assumption held that ordinary civilians had no stake and no interest in the struggle of the princes, hence aiding them would not affect the outcome of 
the war. This is the basis for international humanitarian law that permits outside agents to protect and assist civilians and military hors de combat during war, provided that the assistance is delivered in a neutral manner and has no partisan impact.

How to ensure such neutrality of impact in contemporary conflicts, however, has become an increasing problem of strategy and ethics for humanitarian actors who find that the civilians may also be actively involved in the armed struggle, whether as guerillas and other paramilitary fighters, behind-the-lines duty, or forced labor. Moreover, both states and rebels need a subject population in order to press their claim to rule. Humanitarian support to civilians by long-term care and maintenance therefore can become an important factor in internal conflict, especially in long-term emergencies and when foreign humanitarian presence is critical to survival (e.g. in southern Sudan). The situation has led some humanitarian actors to assess the goodness of their actions at least partly in terms of such consequences.

For all its richness, the major weakness of the study is that it does not systematically raise all the difficult questions that aiding IDPs in conflict situations typically involves. These questions relate to timing, costs, objectives, and consequences of "humanitarian intervention." Equally, they concern the unintended and negative consequences of providing protection and assistance. As noted, this is becoming a growing concern to humanitarian actors. Because aid for IDPs typically occurs under conditions of armed conflict and contested sovereignties, often in poor countries and over long periods, humanitarian aid can easily become a factor in the conflict itself. For instance, supplies are appropriated for military use, or warring factions continue the war in the safe expectation that the international community will sustain the civilians-what Mark Duffield refers to as an international welfare function. Thus, the southern Sudanese rebel leader, John Garang, recently told foreign journalists that he would continue the fifteen-year-old armed struggle, fully confident that international humanitarian agencies would continue to assist the displaced and suffering civilians. Another main concern is that humanitarian response becomes a substitute for more robust conflict management.

These concerns are reflected in many of the case studies, which also demonstrate that unintended and negative consequences can be dealt with. But neither this problem, nor its possible solutions, are lifted out by Deng and Cohen and treated as a central theme. This is particularly worrisome because the undoubted authority and richness of the publication in other respects is likely to make it the standard reference work on IDPs.

Astri Suhrke
The Chr. Michelsen Institute, Bergen,
and The Carnegie Endowment
for International Peace,
Washington, D.C.


Blood and Vengeance: One Family's Story of the War in Bosnia, by Chuck Sudetic (W.W. Norton \& Company 1998), 393 pp.

The suffering of the victims of the war in Bosnia is fading from public view. In 1995 the Dayton Peace Agreement ${ }^{1}$ brought an end to the fighting in Bosnia and to news images of residents of Sarajevo lifting bloody bodies into makeshift ambulances in the wake of another Bosnian Serb mortar attack. Now, the accounts of victims receive only sporadic press attention, largely through reporting on UN-sponsored war crimes trials at The Hague. In light of this, former New York Times correspondent Chuck Sudetic's book is a timely contribution to the growing body of literature on the Bosnian war. Sudetic gives us a more holistic account of the war-one that integrates political developments into the real-life wartime stories of the author's own relatives. The result is a moving and intimate perspective on the causes and impact of the conflict from the perspective of the victims.

While Sudetic has covered Bosnia for the Times, his ties to the region predate his posting. His wife's sister, a Serb and Belgrade native, married a Bosnian Muslim named Hamed Celik. Hamed Celik's family lived in a small village of Serbs and Muslims in eastern Bosnia, called Kupusovici, at the outbreak of the war in 1992. Hamed's family is the fulcrum of the book.

Sudetic traces the history of the Mus- lim Celik family from their arrival in the village at the turn of twentieth century to the fall of the Bosnian town of Srebrenica in 1995-at the time a UN-declared "safe area" - where the family had sought refuge. Through the Celik family, the author depicts the evolution of rural life in Bosnia through World War I and World War II-during which time Muslims and Serbs committed atrocities against each other.

Sudetic's snapshot of life in Yugoslavia after the war forcefully contradicts the myth that ancient ethnic hatreds between Muslims and Serbs led inevitably to war. In fact, the Celik family and the other Muslims in the area lived peaceably with their Serb neighbors during Tito's rule. Violence erupted in the area in 1991, as a result of a plan by the Bosnian Serbs (backed politically and militarily by the President of Serbia, Slobodon Milosevic) to carve out of Bosnia an area "cleansed" of Muslims, which would then merge with the neighboring republic of Serbia to form a "Greater Serbia." As the war advances, Sudetic traces in vivid detail the family's experience of the "ethnic cleansing" of their village, the deprivations of their life as torbari (impoverished refugees) in besieged Muslim enclaves in eastern Bosnia, and their final days in Srebrenica.

Sudetic's method of storytelling is deliberate. He rejects the journalistic framework of a Times correspondent that "focuses mainly on institutions and political leaders and their duties and decisions while leaving the common folk to exemplify trends." ${ }^{2}$ Instead,

1. Dayton Agreement on Implementing the Federation of Bosnia and Herzegovina, signed 10 Nov. 1995, U.N. Doc. AV50/810-S/1995/1021, Annex, reprinted in 35 I.L.M. 170.

2. Chuck Sudetic, Blood and Vengeance: Our Family's Story of the War in Bosnia, at xxxii (1998). 
Sudetic inverts the structure, making the experiences of the Celiks the prism through which the reader sees and understands the effects of the decisions of political leaders. For example, in the final chapter, Sudetic provides the details of the capture and "cleansing" of Srebrenica, an operation that is carefully planned by the Bosnian Serb leadership. In fact, the commander of the Bosnia Serb army, General Ratko Mladić, personally oversaw the mass execution of thousands of captured Bosnian Muslim men, whose shot bodies were bulldozed into unmarked graves. The reader is drawn into the maelstrom and is invited to walk the "trail of death" - the route that thousands of Muslim men have attempted to take out of Srebrenica in order to escape capture-perched on the shoulder of Paja Celik, Hamed's brother. From this intimate vantage point, the reader witnesses the chaos and death that ensues when the Serbs bomb the column of men. The author's detailed account of the capture of Srebrenica is simultaneously riveting and revolting. The reader cannot escape the unbridled brutality of the Serb attack nor deny the chilling passivity of UN and Western leaders, who received clear signs that the assault was imminent. Sudetic succeeds in brokering a special link between the observer and the observed, in part because Sudetic does not romanticize or glorify the plight of the Bosnian Muslims.

While Sudetic clearly focuses on how the Serbs ruthlessly orchestrated and implemented their design to cleanse a large swath of Bosnia of its Muslim inhabitants, he also adds complexity to the tale by exposing the cynicism that infected all parties involved in the conflict. For example, Sudetic provides two notable instances of the Bosnian govern- ment's manipulation of its own Muslim citizens to gain military and political advantage. In the first instance, the Bosnian government exploits the Celik family and other refugees in its attempt to save the remaining pockets of Muslimoccupied territory in eastern Bosnia. In making no attempt to impose discipline, Muslim leaders instead found a use for the terror their own refugees could spread. When Bosnian forces attacked surrounding Serb villages, the impoverished Muslim torbari fanned out, killing Serb civilians and wounded soldiers and pillaging whatever food and supplies they could find.

In the second instance, Sudetic exposes the cynical staging of the images of the civilian casualties of Serb sniper fire in Sarajevo, which were transmitted to international audiences. Many of the pictures, which became symbols of the defenseless Bosnian Muslims, were taken in front of the Holiday Inn, where most foreign news correspondents and photographers stayed. As the cameras clicked, Serb snipers would shoot pedestrians as they crossed the wide boulevard in front of the hotel. However, what was not widely publicized, according to Sudetic, was the fact that the bloody intersection was more like a theater set than a tragic reality of the war because the Bosnian government refused to protect the thoroughfare from attack as it had done at other crossroads, despite pleas from the UN commanders. It turns out that the Bosnian government, apparently, was willing to sacrifice some civilians in order to keep images of the siege conveniently in front of the foreign press.

Bear no mistake, however, that Sudetic makes clear that whatever the Bosnian government's moral shortcomings were, they paled in comparison to 
the United Nations' disastrous peacekeeping policy. The author seems to relish giving the reader behind-the-scenes accounts of how the United Nations actively undermined efforts to stop Serb aggression. For example, in April 1993, Paja Celik was working at the Srebrenica hospital when Serb mortar fire hit a local schoolyard where boys were playing soccer, shattering their bodies as well as a cease-fire. Instead of denouncing the Serb attack, UN officials initially told journalists that the Muslims had fired first and that the Serbs had merely fired in retaliation. While the story was later retracted, it had the effect, according to Sudetic, of laying blame for the breakdown of the cease-fire on the Bosnian government. It serves as one more example of how UN officials tried to absolve themselves of their failure to protect the thousands of Muslim civilians crowded into Srebrenica. The impact of the United Nations' political decision is brought home vividly by the harrowing scene of Paja helping a former neighbor search for her son among the bodies of the school bombing victims; the young man's face was so disfigured by the blast that the only way they were able to identify him was by a mole on his back.

Although written for a general audience, this book is of particular interest to the human rights community. For those concerned with survivors of the Bosnian conflict, the story of the Celik family puts the wartime experiences of rural Bosnians into a fuller context. For observers of Balkan foreign policy issues, the book serves as an important reminder of the human consequences of political decisions. Sudetic's masterful recounting of the experiences of victims to explain the root political causes and human effects of Bosnian war results in a superb and memorable narrative for scholars and activists alike.

Laurel Fletcher Lecturer and Staff Attorney, International Human Rights Law Clinic, Boalt Hall Law School, University of California at Berkeley

\section{Reclaiming Social Rights: Interna- tional and Comparative Perspectives, by Paul Hunt (Aldershot: Dartmouth Publishing Company, Ltd. 1996), 209} pp.

In Reclaiming Social Rights: International and Comparative Perspectives, Paul Hunt, formerly a Visiting Fellow with the Harvard Human Rights Program, now at the University of Waikato, New Zealand, grapples with the historical and political marginalization of social rights, and offers visionary but practical plans for reclaiming them. By "social rights," Hunt means the rights set out in Articles 1114 of the International Covenant on Economic, Social and Cultural Rights (ICESCR), ${ }^{1}$ including an adequate standard of living, food, shelter, health, and education. Hunt seeks a broad audience, focusing on the human rights community, which, as he correctly points

1. International Covenant on Economic, Social and Cultural Rights, adopted 16 Dec. 1966, G.A. Res. 2200 (XXI), U.N. GAOR, 21st Sess., Supp. No. 16, arts. 11-14, U.N. Doc. A 6316 (1966), 993 U.N.T.S. 3 (entered into force 3 Jan. 1976). 
out, has neglected social rights for too long. His is a daunting endeavor, especially for a 209-page book, not only because of the surprising wealth and range of the material, but because some may chafe at the charge of "neglect." Nevertheless, Hunt succeeds brilliantly on all counts.

In the five chapters that make up this book, Hunt engages in what he calls "faltering attempts at an interdisciplinary approach $^{\prime \prime 2}$-one of the few characterizations of the author with which I would take issue. Rather, it is the surefootedness of his approach, in conjunction with the boldness of its overall structure, that makes Reclaiming Social Rights so effective. Each of the five chapters considers social rights from a completely different perspective. However, it not only holds together, but rather dazzles, like a crystal with five distinct facets.

The Introduction provides those new to social rights with a cogent synopsis of their history, theory, and evolving practice. Hunt describes the social rights' eighteenth-century origins, establishing their pedigree, and showing their marginalization from the very beginning. He explains how social rights were linked to the Soviet Union during the Cold War, eventually resulting in the bifurcation of the Universal Declaration of Human Rights. $^{3}$

In theory, by contrast, Hunt shows that it is well recognized that social rights and civil/political rights are indivisible and interdependent, and that both impose "multi-layered" obligations on the state. For example, he cites Henry
Shue's work to show how the state is required to "respect, protect, and fulfill" social rights as well as civil/political rights. ${ }^{4}$ Hunt elaborates that, first, the obligation to "respect" requires the state to legally recognize and refrain from violating rights. Thus, the state can no more bar shipments of grain to a particular region than it can bar freedom of expression. Second, the obligation to "protect" entails preventing rights from being infringed upon by third parties. Here, Hunt uses the example of violence against women by non-state actors to illustrate his point. Third, the obligation to "fulfill" rights requires providing the necessary resources for their enjoyment, whether the result is accomplished by an establishment of a judicial system in connection with civil/political rights or a health care system in connection with social rights. Unfortunately, social rights are neglected at each of these levels.

Hunt then describes the UN Committee charged with overseeing the ICESCR (the CESCR), noting its progressive and proactive jurisprudence. He points out that it was one of the first of the UN Committees to accept statements from NGOs. Unfortunately, however, the response to date has been disappointing. He attributes the problem to the gaps between international institutions and those most in need of their protection, and the dearth of NGOs to fill them. He adds that it also reflects the difficulties inherent in holding states accountable to the most vulnerable of their people, those who lack the political clout neccessary to make a difference. For

2. Paul Hunt, Reclaiming Social Rights: International and Comparative Perspectives, at xvij (1996).

3. Universal Declaration of Human Rights, adopted 10 Dec. 1948, G.A. Res. 217A(III), U.N. GAOR, 3d Sess. (Resolutions, pt. 1), at 71, U.N. Doc. A/810 (1948), reprinted in 43 AM. J. INT'L L. SUPP. 127 (1949).

4. Id. at 31 (citing Henry Shue, Basic Rights: Subsistence, Affluence, and US Foreicn Policy 52 (1980)). 
instance, in the context of the debates over choosing to support either "free trade" - that is, trade unencumbered by labor and environmental regulationsor "fair trade," even developing states choose "free trade" at the expense of human rights. Nevertheless, Hunt convincingly shows why human rights approaches are so critical to global social policy, leaving his analysis of the extent to which existing approaches can effectively address the problems to the final chapter in his book.

The Introduction concludes with a list of concrete objectives. The author's focus and insistence on articulating practical measures to achieve specific goals is the key to his book's success. He is straightforward about his "view, [that] rights can make a positive contribution to this struggle for social change." ${ }^{5} \mathrm{How}-$ ever, Hunt avoids rhetoric, offering instead nuanced analysis-"One approach among many, [the role of social rights] should be neither idealized, nor exaggerated, nor ignored."6

In Chapter One, Hunt begins to shape a functional role for social rights by critically examining the usual justifications for treating "first-generation" civil rights and "second-generation" social rights as different. He problematizes the conventional wisdom that first-generation rights are "negative,"-thus requiring the state to do nothing-while second-generational rights are "positive"requiring affirmative, often costly, measures on the part of the state-to show that the two kinds of rights are in fact quite similar. Hunt summarizes the ex- isting rights literature, buttressing his argument with the domestic budgets of New Zealand and Canada, as well as the decisions of national and regional courts, including the US Supreme Court and the European Court of Human Rights. For example, he shows that fiscal constraints have consistently been rejected as an excuse for the denial of civil and political rights in prison conditions litigation. Refuting the canard that courts cannot "do policy," Hunt demonstrates that justiciability is merely one element, and that social rights are better conceptualized as having a "'hard' justiciable core as well as a more soft programmatic element." 8 The author concludes Chapter One, ironically, by pointing out that the single most important difference between first and second generation rights may well be the lack of legal tradition in connection with the latter. Thus, he argues that despite the lack of defensible distinctions between these categories, the perception of difference itself is significant.

As Hunt explains at the beginning of Chapter Two, social rights have two dimensions of marginalization. First, they are juridically marginalized within national and international legal systems. Second, they have special relevance to marginalized groups. He ably supports this thesis by examining the marginalization of women in New Zealand and Australia. Because my research centers on women's rights, much of this is familiar ground, and I appreciate how expertly Hunt maps it. For example, Hunt recites the well-known international statistics

\footnotetext{
5. Id. at 41 .

6. Id.

7. See id. at 65 .

8. Id. at 69 (quoting A. Rosas, The implementation of economic and Social Rights: Nordic Legal Systems, in 3 The Implementation of Economic and Soclal Rights: National, International, and Comparative Aspects 235 (1991).
} 
that women work more, earn less, are less educated and, in the developing world, are less literate, have less food, health care, and education. ${ }^{9}$ He then shows how social marginalization is reflected in political marginalization by citing New Zealand's statistics on women in public office. ${ }^{10}$

Although Hunt generally eschews anecdotes in favor of hard data, in this chapter he offers vivid sketches of daily life for women from four different countries. ${ }^{11}$ While their lives are very different, each spends much of her time in non-market "women's work." Their stories show why measures that fail to address the underlying social conditions that shape women's lives cannot assure substantive equality. For this reason, Hunt argues that activists should keep social rights in mind as an option in formulating strategies for the promotion of substantive rights. For example, Hunt notes that, because affirmative action has already played a constructive role in the education and employment contexts, why not extend it to health care entitlements or even "more ambitious proposals like the provision of a social wage or basic income"? ${ }^{12}$ The author concludes Chapter Two by noting that while social rights are not a panacea, they can be a useful tool to counter women's marginalization.

In Chapter Three, Hunt shifts his focus from a particular group to a particu- lar right, the right to health. He points out that, despite the universality of the right to health, it is not widely recognized. Hunt attributes that partly to the World Health Organization's (WHO) aversion to legal strategies. In addition, the author notes that the right to health is neither well-defined nor well-understood. For clarification, Hunt first examines several legal instruments, and then returns to Shue's tripartite framework requiring the state to "respect, protect, and fulfill" human rights. Citing Virginia Leary's groundbreaking work, the author explains that the state respects the right to health by barring torture by state agents and refraining from the use of nuclear weapons. ${ }^{13}$ Quoting Audrey Chapman, who has also relied on Shue's framework, Hunt argues that the duty to protect requires the state "to preserve or restore clean air and water, reduce exposure to toxic substances, and assure work place safety." ${ }^{\prime 4}$ The duty to fulfill, according to Leary, requires the state "to adopt primary health care with all that it implies, including emphasis on preventive rather than curative measures."15 Building on this work, Hunt concludes that the "literature [related to health and human rights] is growing, networks are developing, [and] our understanding of the right to health is deepening." ${ }^{16}$ However, noting NGOs' continuing neglect of the right to health, Hunt suggests ten elements for an international NGO pro-

\section{Id. at 72 .}

10. $I d$

11. Id. at 76-77 (Ghana, Guatemala, North America, and Zimbabwe).

12. Id. at 104 .

13. Id. at 131 (citing Virginia Leary, The Right to Health in International Human Rights Law, 1 Heatth \& Hum. Rts. 11 (1993)).

14. Id. at 132 (quoting Audrey Chapman, Exploring a Human Rights Approach to Health Care Reform 28 (1993)).

15. Id. at 133 (quoting CHAPMAN, supra note 13 , at 51 ).

16. Id. at 146. 
gram to further this right. These range from obvious measures, such as the exchange of information between human rights bodies, to an ambitious call for international standard setting.

In Chapter Four, Hunt shifts focus from a particular right to a particular country, India. The Indian Experience is an account of that troubled state's recent efforts to promote social rights. Hunt explains that, under the activist Supreme Court of Chief Justice Bhagwati, the Indian Constitution has proven to be a flexible tool in developing social action litigation. For example, the traditional rules of standing, which required a financial or property interest in the litigation, were liberalized to allow "epistolary" jurisdiction, thus making it possible to bring a matter before the court by writing a letter on behalf of the poor. Furthermore, court-appointed commissions were given the task of fact-finding and remedies included court-initiated affirmative action. Despite the fact that escalating burden on the courts leaves the future of such procedures in question, Hunt draws on India's experience to conclude that social rights require that the courts be easily accessible to the disadvantaged, have fact-finding powers, have the capacity to enter detailed orders, and have monitoring capacity. ${ }^{17}$

The final chapter skillfully integrates the mechanisms described earlier with some new tactics to sketch five broad approaches. First, Hunt introduces the work of sociologist T.H. Marshall to highlight the need for an interdisciplinary dialogue and a focus on an interna- tional "social element [to] abate the injustices of globalization. ${ }^{\prime 18}$ Second, he draws on the Canadian Draft Social Charter to show how metaphors shape approaches to rights. For example, in the Draft Social Charter, rights are not conceptualized as "trumps" but as "sites of dialogue," reflecting the "need to create space for the voices of the disempowered."19 Third, Hunt examines national human rights institutions, using the Australian Human Rights Commission as an example. He notes that although the Commission is responsible for compliance with several human rights instruments, the ICESCR is not part of its mandate. Nevertheless, "social rights permeate the various instruments for which [the Commission] is responsible," ${ }^{20}$ and it has produced "a sophisticated policy document with substantive social rights content. ${ }^{21}$ The Commission is also considering the need for new domestic human rights institutions.

Fourth, Hunt offers a brief but insightful analysis of the World Bank's potential for furthering human rights. He explains the Bank's practice of conditioning loans on policy change (the infamous "structural adjustment programs" or "SAPs") and describes the resultant polarization of income and declining standards of human welfare. Questioning the human rights community, Hunt wonders how economic institutions can be encouraged to take social rights more seriously. He then suggests three practical answers. First, he argues that "human rights impact statements," modeled after environmental impact statements,
17. Id. at 171.
18. Id. at 184 .
19. Id at 186.
20. Id. at 191 .
21. Id. at 192. 
should be required. Second, he insists that the Bank should be bound by human rights law as a UN agency with a policymaking capacity-although he recognizes that the extension of human rights obligations to a non-state actor is still problematic. Third, Hunt describes the recently created Inspection Panel of the Bank, which by having the power to investigate complaints regarding the "Bank's failure to follow its operational policies and procedures, ${ }^{22}$ could also bear upon social rights issues. Finally, Hunt considers the connections between these three approaches, concluding that there are ample opportunities for making the Bank more responsive to human rights concerns. However, he points out that these opportunities will be missed unless NGOs devote more time and resources to social rights.

This segues into the final approach, an "international NGO program" for social rights. Hunt points to recent developments in that field to suggest that NGOs' historical neglect of social rights is abating. He describes the Bangalore Declaration and Plan of Action, ${ }^{23}$ which called on human rights lawyers to take social rights more seriously, and concludes with ten specific, concrete suggestions for further work, ranging from monitoring and using CESCR procedures to bring national and local issues to the Committee's attention, to conceptual work, standard setting, and institutional design.

In conclusion, Reclaiming Social Rights is an invaluable resource. Its usefulness is further enhanced by the ten appendices, which contain social rights documents unavailable in any other single source. Its major weakness is its brevity. The author repeatedly "sketches" or "illustrates" where a more comprehensive exploration would be welcome. However, this is a quibble that the author himself readily concedes, and it is unlikely to be perceived as a flaw by the human rights advocates who are its target audience. While Hunt provides rich material for the theorists, this book is clearly intended for those actively engaged in promoting human rights. Hunt's rigorous scholarship, his accessible prose, the acute sensibility with which he integrates disparate sources, and the passion he brings to his subject make Reclaiming Social Rights a superb introduction, and call to action, for those who hope to make social justice a reality.

\section{Barbara Stark University of Tennessee College of Law}

22. Id. at 201.

23. Bangalore Declaration and Plan of Action, adopted 25 Oct. 1995; id. at 231. 
The Death Penalty: An Historical and Theological Survey, by James J. Megivern (New York: Paulist Press 1997); Against the Death Penalty: Christian and Secular Arguments Against Capital Punishment, by Gardner C. Hanks (Scottdale, Pa.: Herald Press 1997).

The Christian Church and the Problem of Capital Executions: Killing in the Name of the Lord?

In 1976, US bishops in the Catholic Church appealed to the Pontifical Commission for Justice and Peace in Rome to help settle a debate on capital executions. The Pontifical Response said that the "bishops have spoken out and acted firmly in defense of life against abortion and euthanasia. ... There is an inner logic that would call Catholics, with their sense of the sacredness of life, to be consistent in this defense and extend it to the practice of capital punishment." This document encouraged more bishops to take a stand against state executions, in the same year that the Supreme Court lifted its 1972 ban by declaring certain "capital punishment" statutes constitutional in Gregg v. Georgia. ${ }^{2}$

Such is the principle of "the consistent ethic of life"-the ideal that every life is sacred and that a human cannot take the right to life from another human, whether it be an unborn fetus, combat soldier, terminally ill patient, or convicted murderer. From a Christian perspective in the United States, this is a troubling situation. Those of us within the faith are essentially united against the practice of abortion, but seem divided when it comes to capital execution. At a time when the majority of US citizens offer support for state executions ("tough on crime"), the silence of Christian voices is unusual and confusing in light of the Church's anti-abortion activism.

In 1997, two Christians-one Catholic and one Protestant-made their voices heard. Dr. James J. Megivern, a philosophy and religion professor at the University of North Carolina, Wilmington, concluded his work, The Death Penalty: An Historical and Theological Survey, a project that had its genesis in 1979. Gardner C. Hanks also introduced his work, Against the Death Penalty: Christian and Secular Arguments Against Capital Punishment, in 1997. Hanks wears many hats, among them professional librarian at Idaho State Library and the Idaho State Death Penalty Action Coordinator for Amnesty International. He also has served as spiritual advisor for Idaho death row inmates, and is active in the Mennonite Church.

Megivern's work attempts to explain how capital execution has lasted so long in Christian societies. From the Preface:

The lack of English-language histories that explained how capital punishment came to be the common practice throughout centuries in Christian Europe I found puzzling. How had it come about that churchmen in the High Middle Ages had adopted a position of staunch support of this singular practice of deliberately destroying human life? There simply had to be more of a story behind this intriguing phenomenon, but, whatever it was, the standard literature did not seem to include it. The

1. James J. Megivern, The Death Penalty: An Historical and Theological Survey 354 (1997) (quoting 6 Oricins, 9 Dec. 1976, at 391).

2. 428 U.S. 153 (1976). 
widely used church histories, especially, were strangely silent, seeming to take it for granted that there was nothing incongruous in such endorsement. ${ }^{3}$

Megivern's 641-page volume then tackles the history of capital execution, and the role of Christianity in it, in chronological order. The Death Penalty covers the time period of A.D. 175 through 1996 in eleven chapters. Roughly half of the book is devoted to the twentieth century alone, largely due to the scarcity of records from earlier times. Megivern picks up on the early church after the record of the New Testament, when Christians were an oppressed religious group under the harsh Roman regime and likely victims of executions themselves. It continues through the establishment of Christianity as the official Roman religion, which resulted in an even harsher penal code, now bearing the mark of divine authority. For centuries, the Church sank itself deeper and deeper into a pattern of violence as it struggled to defend itself against heresy. Execution became a major tool in this battle. During this era, church officials kept themselves "clean" by handing the offenders over to the state arm for punishment. One of the principal arguments for execution at this time was the analogy of the gangrenous limb: if the Church is the Body of Christ and a member of that Body is "poisoned" with a homicidal (or heretical) sickness, the proper solution is to remove that member in order to protect the overall Body from this sickness.

The survey continues into the Enlightenment period and a time when voices of dissent against capital executions be- came louder. Megivern traces the beginning of change in the Catholic Church in Europe, and shifts the focus to the United States in the twentieth century, meanwhile noting significant events from other parts of the world, such as the dates that other nations abolished the practice, as they fit into the chronological context. The struggle of US bishops and their eventual majority turnaround to oppose the practice that for centuries was sanctioned and staunchly defended by their own religion is detailed, as are modern legal developments in US capital executions.

Throughout his survey, Megivern provides the positions of Christian thinkers on this subject in their own words, and it is evident that Megivern's research is exhaustive and thorough. St. Augustine's initial rejection of using violence to correct heretics and eventual, grudging softening to such practices, largely brought about by the increasing violence of the times, is described and assessed. St. Thomas Aquinas' elaboration of his support of executions, drawing upon the gangrenous limb analogy, is also provided. Megivern strives to place all of these voices within the context of the very real and violent social upheaval in which Christian people lived. The burning of heretics was for a while merely accepted by the majority and opposed by the minority, but as it continued, opposition to the practice itself branded one with heresy and became a dangerous and punishable offense. The Death Penalty does an excellent job of placing the reader in those times and maintaining perspective on the enormous uphill battle that would have to be fought

3. Megivern, supra note 1 , at vii. 
before people could even talk about abstaining from execution.

Just as The Death Penalty was begun in its earliest stages in 1979, that same year marked a milestone for Gardner Hanks with respect to his position on state executions. Though he was already opposed to the practice, Hanks did not see the issue come to the forefront of his own life until 1979, when he joined others in actively protesting the upcoming execution of John Spenkelink in Florida. (Spenkelink became the first unwilling victim of state execution in the United States since 1967.) This experience, and especially the living witness of the Presbyterian Church that organized the protest and various Christian ministers who participated in it, eventually led Hanks to embrace the Christian faith shortly thereafter. Hanks went on to live in states that did not impose capital execution for the next nine years, but moved to Idaho in 1989 and resumed his activism against the practice. This led him eventually to a state leadership role within Amnesty International and to become the spiritual advisor for death row inmates.

Faced with a slowdown in his work for Amnesty, Hanks felt the need to work on another project. He decided to write the book that he had wished was available for people struggling with and working on the issue of capital executions: a single "reference source in which the various arguments against capital punishment were compiled along with pertinent facts, statistics, anecdotes, and quotes that supported those arguments." As a man of faith, Hanks' objections are based primarily on the example of Jesus
Christ. However, he wanted to write for a secular audience as well, to allow all advocates of abolition to have access to arguments based on both religious principle and practical and social rationale. The more complete an activist's understanding is of both types of arguments, the better prepared that activist will be when arguing the issue.

Hanks' slim, 207-page book is neatly organized, breaking down the complex issue of execution into its many components: one chapter apiece devoted to perspectives from the Old and New Testaments of the Bible; two chapters tracing historical opposition; two chapters on the deterrent effect (or lack thereof) of capital executions; and individual chapters on repeat offenders; the needs of crime victims; the significance of race, mental retardation, and economic class (three separate chapters); execution of the innocent; the cost of executions; the societal effects of the practice; execution as cruel and unusual punishment; and a conclusion. In addition, Hanks provides the following appendices:

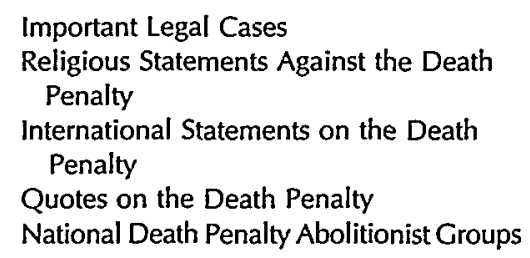

Of course, at 207 pages, Against the Death Penalty does not provide exhaustively detailed responses to each of those sub-issues. Rather, it sketches out important points organized within each chapter by subheadings to familiarize the reader

4. Gardner C. Hanks, Against the Death Penalty: Christian and Secular Arguments Against Capital Punishment 15 (1997). 
with the arguments, rationale, and support for each sub-issue, often with more details and elaboration provided in the endnotes. There are times when the objective reader will question some of Hanks' blanket definitive statements-for example, "All of this shows that the use of capital punishment does not deter crime. ${ }^{\prime 5}$

Readers will also want to consult other works listed in the bibliography if they are preparing for a serious academic or legal debate on the topic. This is not to say Against the Death Penalty is not a legitimate and valuable resource, but rather to recognize the book as a concise summary and compilation of arguments and data, and not a comprehensive, firsthand academic research work on executions. That being said, it is difficult to imagine any open-minded reader walking away from this book and still maintaining staunch support for the practice of state executions without at least some serious doubts about its effectiveness and morality.

Neither Megivern nor Hanks attempts to hide his own personal conviction that capital executions are immoral, ineffective, and unjustifiable from a Christian Gospel perspective (the same is true for this reviewer). Megivern inserted many articulate, subjective statements into his survey that point out how absurd and barbaric these practices have been. Hanks essentially concludes each of his chapters by stating how that particular sub-issue weighs in favor of abolition. Perhaps defenders of execution will find this "lack of objectivity" frustrating. However, an argument can be made that the facts, arguments, examples, and data put forth by these authors would inevitably lead any objective, open-minded student on the topic to the same conclu- sion. Regarding the burning of humans at a stake for the purpose of enforcing religious beliefs as barbaric can hardly be seen as a biased or subjective viewpoint; perhaps in the future, the same will be said for government executions of condemned criminals by suffocation with poison gas, or burning from the inside out with electricity, or by hanging or firing squad, which practices are still in use in this day and age in some states.

This reviewer considers it shameful and embarrassing that the Christian faith, with overwhelming majority support from its members, has been applied inconsistently to battle abortion as an important political and moral issue while still maintaining collective silence on the issue of capital executions due to the division and inaction from within. Because our government has ruled that execution is acceptable and because most citizens also embrace it, the Church's silence translates in practical effect to acceptance of the practice in the modern era. Leaders of the Catholic Church, along with several other churches listed in Hanks' appendix, have drawn the battle lines, denounced and rejected the practice, and appealed to government authorities. But the lack of united Christian opposition to this practice is bewildering, especially considering that we practice a faith that has compassion, mercy, forgiveness, and love at its very heart, and considering that we strive to imitate a man who subjected Himself to execution on the cross for the very purpose of giving humankind a second chance. Considering the purpose and heart of Christ, His followers should be the most vocal and the most active opponents of execution of the fallen.

It is thus encouraging that these works

5. Id. at 83 . 
were published. Two different Christian authors, one of them a Catholic academic, the other a Protestant grassroots activist, have provided two different volumes on the common theme of capital execution from a Christ-based perspective. Both are excellent reference sources, and both are worthy companions of each other.

Megivern's The Death Penalty is an exhaustive historical survey that traces the practice through the centuries, especially with regard to church involvement, and that offers the reader a valuable oversight of this history and a look at the positions of Christian voices, both in support of and opposition to execution, throughout the Church's history. Hanks' Against the Death Penalty is a compact, concise, and neatly organized walk through the issue of capital execution that serves as an outstanding starting point for people, within the Christian faith and without, who want to dig past the evening news and political soundbites and really inform themselves on the many. components of the debate. Although it is not devoted exclusively to dealing with Christian arguments and is not exclusively targeted to a Christian audience, and a large portion of it addresses the non-religious practical and social elements, it is nonetheless important to have such a book created by a Christian author who identifies with Christian readers and who incorporates relevant Christian beliefs into the discussion.

The acceptance and passivity of American citizens to government-authorized killings is alarming. We need to inform ourselves and others about all the issues that make this such a troubling practice: discriminatory impact, killing of minors and the mentally retarded, mistaken killing of the innocent (which the evidence indicates is not eradicated from our system), high financial costs that could go toward more productive ends, the barbarism and torture of execution and the wait on death row, the lack of deterrence, and the alternatives we have to protect our society. Christians also need to be honest with ourselves, challenge public opinion, and confront these issues in light of Christian salvation and mercy. We need to expose politicians who use this awful system to further their own careers (the mistaken assumption that execution equals "tough on crime"). We must strive to achieve these aims without losing sight of the need to care for victims of capital crimes and their families, and the need to solve problems of prison conditions and overcrowding. We must take the time now to decide these issues based on rationale and principle, and not wait until wellpublicized and heinous crimes drive us to decide based on rage and hatred. Most importantly, if we (as a society or as a church) cannot unanimously decide one way or the other, if there are uncertainty and ambiguity, we must favor the presumption of life and not kill unless we absolutely know it is both necessary and moral. This is the type of message that Christian and social activists such as Megivern and Hanks are putting forth in their works, and these works need to be read up on or we as a society will trudge on in ignorance and blindness.

Jonathan Snyder J.D., University of Cincinnati Articles Editor, Human Rights Quarterly, 1996-1997 